\title{
Chemical and biological-based isoprene production: Green metrics
}

\author{
Ana R.C. Morais ${ }^{\mathrm{a}}$, Sylwia Dworakowska ${ }^{\mathrm{b}}$, Alberto Reis ${ }^{\mathrm{a}}$, Luisa Gouveia ${ }^{\mathrm{a}}$, \\ Cristina T. Matos ${ }^{\mathrm{a}}$, Dariusz Bogdał ${ }^{\mathrm{b}}$, Rafał Bogel-Łukasik ${ }^{\mathrm{a}, *}$ \\ a Laboratório Nacional de Energia e Geologia, I.P., Unidade de Bioenergia, Estrada do Paço do Lumiar 22, 1649-038 Lisboa, Portugal \\ ${ }^{\mathrm{b}}$ Department of Biotechnology and Physical Chemistry, Faculty of Chemical Engineering and Technology, Cracow University of Technology, Warszawska 24, \\ 31-155 Cracow, Poland
}

\section{A R T I C L E I N F O}

\section{Article history:}

Received 18 July 2013

Received in revised form 20 May 2014

Accepted 21 May 2014

Available online 28 June 2014

\section{Keywords:}

Green metrics

Isoprene

Escherichia coli

E-factor

Economic evaluation

Land use

\begin{abstract}
A B S T R A C T
Green metrics is a methodology which allows the greenness of either new or already existing processes to be assessed. This paper is a part of a special issue devoted to green metrics in which this methodology is applied to different processes to assess bio and petrochemical routes. In this work, green metrics were used as a tool to validate and compare the petrochemical and biological processes of isoprene production. The Sumitomo process has been selected for this comparison as it is beneficial because of it using less expensive $C_{1}$ components as well as the fact that it has lower investment costs for a single-step process. The production of isoprene through a modified Escherichia coli bacterial process has been selected for comparison with the fossil pathway. The green metrics evaluation was performed for both processes to produce isoprene and to target 50,000 tonnes of isoprene yearly.

Although, the calculated costs for the bio-isoprene are slightly higher than the actual market price of its fossil counterpart, the results obtained reveal that the bacteria-based isoprene production is able to substitute the petrochemical process, with material and energy efficiency. This conclusion has also been proved by the increasing number of industrial interest in bioisoprene. The challenge comes from the land use needed for the production of a carbon source which might be solved by the use of waste and residues which are rich in carbohydrates or lignocellulosic biomass which can be converted to simple sugars.
\end{abstract}

(C) 2014 Elsevier B.V. All rights reserved.

\section{Introduction}

Isoprene $\left(\mathrm{C}_{5} \mathrm{H}_{8}, 2\right.$-methyl-1,3-butadiene $)$ is a hydrocarbon, which is colourless and a volatile liquid at room temperature. Isoprene occurs extensively in nature at very low concentrations being metabolised by several organisms such as animals, plants (including macro- and microalgae), fungi and bacteria [1-3].

Isoprene is a key chemical commodity required to manufacture a diverse range of industrial products, including (in over of 95\%) a wide variety of elastomers used in surgical gloves, motor mounts, rubber bands, golf balls, condoms and shoes. However, the most important use of isoprene is the production of synthetic rubber (cispolyisoprene) in tire manufacturing (cars and trucks). Furthermore, $5 \%$ of the worldwide production of isoprene is dedicated to produce chemicals, which are used as intermediates for pharmaceuticals, vitamins, flavourings, perfumes, and epoxy hardeners $[2,4,5]$.

\footnotetext{
* Corresponding author. Tel.: +351 210924600.

E-mail addresses: pcbogdal@cyf-kr.edu.pl (D. Bogdał), rafal.lukasik@lneg.pt (R. Bogel-Łukasik).
}

Isoprene was first synthesised in 1860 by C.E. Williams through the pyrolysis of natural rubber. Nowadays, most isoprene production comes from fossil fuel resources. The three major producers of high-purity isoprene are Nizhnekamskneftekhim, SynthezKauchuk and Togliattikauchuk from Russia with a production of 427,500 tonnes in 2011. The next largest world producers of isoprene are Goodyear and Shell (USA) [6]. Dehydrogenation of isopentane as well as synthesis of isoprene from isobutylene and formaldehyde are commonly used in Russia, whereas direct isolation of isoprene from $\mathrm{C} 5$ stream by extractive distillation is executed in the USA [7]. Global industrial production of synthetic isoprene from petrochemical feedstocks is close to 1 million tonnes per year and currently isoprene consumption is around 850,000 tonnes annually [8]. A large amount of the isoprene produced annually is liberated by plants which collectively release approximately 500 million tonnes of carbon per year [9], making isoprene the dominant gaseous hydrocarbon produced by vegetation. This amount of isoprene is sufficient to produce 60 billion car and truck tyres, which is 50 times the current global manufacturing of 1.2 billion tyres [2]. However, the use of isoprene from plants and animals for commercial purposes is still economically 